\title{
Identification of an Invariant Response: Stable Contact with Schwann Cells Induces Veil Extension in Sensory Growth Cones
}

\author{
Michael Polinsky, ${ }^{1}$ Kenneth Balazovich, ${ }^{2}$ and Kathryn W. Tosney ${ }^{2}$ \\ Departments of ${ }^{1}$ Neurosurgery and ${ }^{2}$ Biology, The University of Michigan, Ann Arbor, Michigan 48109
}

Growth cones sense cues by filopodial contact, but how their motility is altered by contact remains unclear. Although contact could alter motile dynamics in complex ways, our analysis shows that stable contact with Schwann cells induces motility changes that are remarkably discrete and invariant. Filopodial contact invariably induces local veil extension. Even when contacts are brief, veils always extend before the filopodia retract. Contact at filopodial tips suffices for induction. Moreover, veils extend significantly sooner than on filopodia contacting laminin, which often detach without extending veils. The overall behavioral responses of the growth cone, such as increased area and turning, result from integrating multiple discrete responses. Cycles of veil induction enlarge the growth cone and often lead it onto the cell. Invariant veil induction is abolished by blocking $\mathrm{N}$-cadherin signaling. We propose an axonal guidance model in which different guidance cues act by inducing different but discrete and invariant responses.

Key words: axonal guidance mechanisms; filopodia; G-proteins; growth cones; guidance cues; N-cadherin; pathfinding mechanisms; Schwann-neurite interactions; sensory neuron guidance; veils
To reach their targets, neurites trace out intricate paths by responding to environmental cues (Tosney, 1991; Goodman and Shatz, 1993). The cues are detected by growth cones that dynamically extend actin-rich processes organized as cylinders (filopodia) or flat sheets (lamellipodia or "veils"). Extensions may retract or may fill with cytoplasm ("engorge") and thereby extend the growth cone (Goldberg and Burmeister, 1986). Extension is essential for pathfinding. When extension is experimentally prevented, growth cones still advance but lose pathfinding ability (Marsh and Letourneau, 1984; Bentley and Toroion-Raymond, 1986). The filopodia detect environmental cues and somehow transmit information that can alter growth cone direction. Stable filopodial adhesion is suspected to modulate second messenger systems that alter cytoskeletal dynamics and hence, trajectory (Marsh and Letourneau, 1984; Caudy and Bentley, 1986; Gunderson, 1987; Aletta and Greene, 1988; Burmeister and Goldberg, 1988; Forscher, 1989; Goldberg and Burmeister, 1989; Schuch et al., 1989; Calof and Lander, 1991; Gomez and Letourneau, 1994).

Contact could influence motility stochastically, by altering motile characteristics on a probability basis, or it could influence motility selectively, by invariably altering a distinct characteristic such as the adhesion, lifetime, number, size, or stability of processes. Such highly selective responses have been recently reported. Stable filopodial contact with two cell types induces discrete and invariant motile changes (Oakley and Tosney, 1993; Steketee and Tosney, 1999). Stable contact with anterior sclerotome cells stimulates veil and filopodial extension throughout the growth cone and locally induces contacting processes to consolidate. Stable contact with posterior sclerotome cells locally prohibits veil extension. Similarly discrete responses are seen in

Received May 19, 1999; revised Oct. 8, 1999; accepted Nov. 8, 1999.

This work was supported by National Institutes of Health Grant NS21308. We thank Mike Steketee for comments.

Correspondence should be addressed to K. W. Tosney, The Department of Biology, Natural Science Building, 830 North University, The University of Michigan, Ann Arbor, MI 48109-1048. E-mail: ktosney@umich.edu.

Copyright (C) 2000 Society for Neuroscience $0270-6474 / 00 / 201044-12 \$ 15.00 / 0$ other systems. Filopodia contacting guidepost cells in insects preferentially engorge (O'Connor et al., 1990; Myers and Bastiani, 1993). Some cues abolish the ability to extend locally ("local collapse": Fan and Raper, 1995); some cause selective pruning of filopodial extensions (Burmeister and Goldberg, 1988; Stretavan and Reichardt, 1993); others locally alter how many filopodia extend (Myers and Bastiani, 1993).

The present study asks if another physiologically relevant behavior, a growth cone enlargement and rapid spread onto Schwann cells (Letourneau et al., 1990), is mediated by an equally discrete and invariant response. Examining filopodial and veil dynamics shows that stable contact with Schwann cells does invariably stimulate a discrete response, veil extension. This veil induction suffices to alter growth cone size and trajectory.

If truly physiological, these invariant responses should result from invariant molecular contacts that act through second messengers to alter the local cytoskeletal dynamics selectively. If so, disrupting the relevant signaling cascade may only diminish overall behavioral responses like turning or spreading (products of several forces) but should abolish the invariant response. Therefore, interventions were repeated that diminish the behavioral response to Schwann cells (Letourneau et al., 1990). The findings establish that blocking functions of $\mathrm{N}$-cadherin or G-proteins abolishes the invariant veil induction. The results reveal that stable filopodial contact, mediated by $N$-cadherin and involving G-proteins, induces a discrete and invariant response. The invariant response leads to growth cone enlargement and biases trajectory toward advance onto Schwann cells.

\section{MATERIALS AND METHODS}

Cell culture. Chicken embryos (6.5-d-old, stage 28-30; Hamburger and Hamilton, 1951) were washed in Puck's saline G, decapitated, eviscerated, divested of their notochord, spinal cord, and meninges, and again thoroughly washed. Dorsal root ganglia (DRG) were isolated from the hindlimb region and transferred into Ham's F-12 media supplemented with $10 \%$ heat-inactivated horse serum, antibiotics (Life Technologies, Gaithersburg, MD), $50 \mathrm{ng} / \mathrm{ml}$ nerve growth factor, $20 \mathrm{~mm}$ HEPES buffer, and hormone additives (Bottenstein et al., 1980). DRG were divided 
Table 1. The invariant veil extension on contact with Schwann cells is not a function of the type on duration of filopodial contact

\begin{tabular}{|c|c|c|c|c|c|c|c|c|c|}
\hline \multirow[b]{2}{*}{ Contact type } & \multirow[b]{2}{*}{ Substrate } & \multirow{2}{*}{$\begin{array}{l}\text { \# of } \\
\text { contacts }\end{array}$} & \multirow{2}{*}{$\begin{array}{l}\% \text { with } \\
\text { veils }\end{array}$} & \multicolumn{3}{|c|}{$\begin{array}{l}\text { Filopodia extending veils: duration } \\
\text { of contact, min }\end{array}$} & \multicolumn{3}{|c|}{$\begin{array}{l}\text { Filopodia without veils: duration } \\
\text { of contact, min }\end{array}$} \\
\hline & & & & Mean $\pm \mathrm{SD}$ & Median & Range & Mean $\pm \mathrm{SD}$ & Median & Range \\
\hline \multicolumn{10}{|l|}{ Non-contacting: filopodium moves } \\
\hline over the substrate without hesitating & Laminin & 115 & $48 \%$ & 0 & 0 & 0 & 0 & 0 & 0 \\
\hline & Schwann & 8 & $25 \%$ & 0 & 0 & 0 & 0 & 0 & 0 \\
\hline \multicolumn{10}{|l|}{$\begin{array}{l}\text { Hesitating: filopodial tip unmoving for } \\
0.1-0.9 \mathrm{~min} \text {; filopodium fails to }\end{array}$} \\
\hline $\begin{array}{l}\text { 0.1-0.9 min; filopodium fails to } \\
\text { straighten }\end{array}$ & Laminin & 46 & $29 \%$ & $0.21 \pm 0.12$ & 0.20 & $0.1-0.4$ & $0.28 \pm 0.17$ & 0.20 & $0.1-0.6$ \\
\hline & Schwann* & 3 & $100 \%$ & $0.83 \pm 0.06^{*}$ & $0.80^{*}$ & $0.8-0.9^{*}$ & - & - & - \\
\hline \multicolumn{10}{|l|}{ Transient: filopodial tip unmoving for } \\
\hline \multirow[t]{2}{*}{ 0.1-0.9 min; filopodium straightens } & Laminin & 91 & $54 \%$ & $0.42 \pm 0.22$ & 0.40 & $0.1-0.9$ & $0.47 \pm 0.26$ & 0.50 & $0.1-0.9$ \\
\hline & Schwann & 9 & $100 \%$ & $0.50 \pm 0.30$ & 0.35 & $0.1-0.9$ & - & - & - \\
\hline \multicolumn{10}{|l|}{ Stable: filopodial tip unmoving for } \\
\hline \multirow[t]{2}{*}{$\geq 1.0$ min; filopodium straightens } & Laminin & 97 & $42 \%$ & $2.00 \pm 1.30$ & 1.50 & $1.0-5.8$ & $1.90 \pm 1.2$ & 1.60 & $1.1-7.9$ \\
\hline & Schwann & 87 & $100 \%$ & $3.25 \pm 2.15$ & 2.50 & $1.0-12.0$ & - & - & - \\
\hline
\end{tabular}

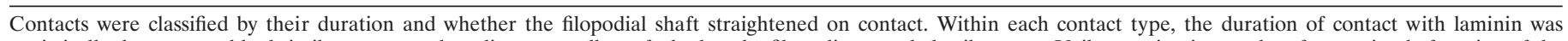

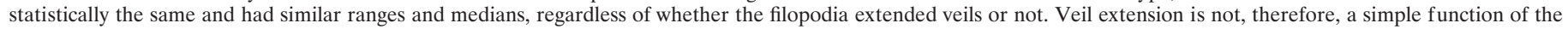

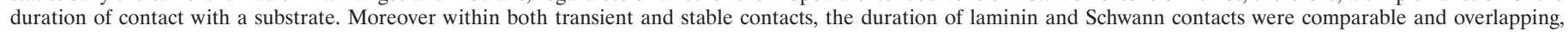

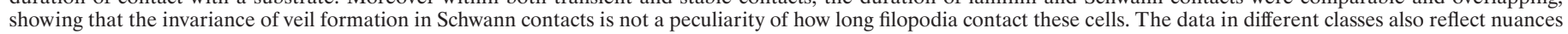

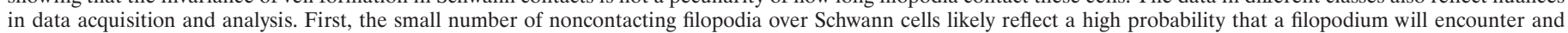

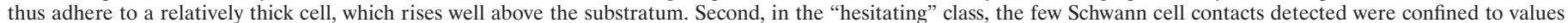

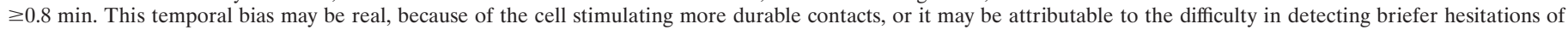

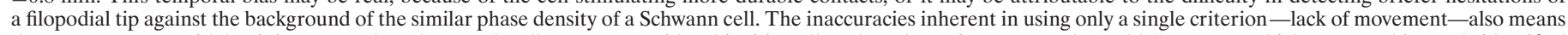

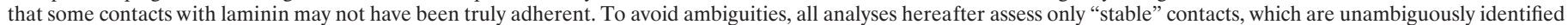

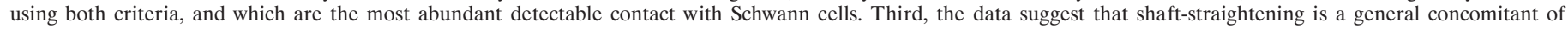

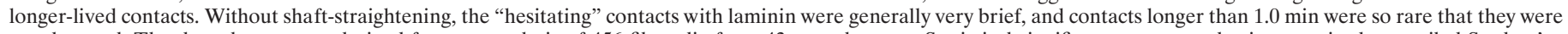

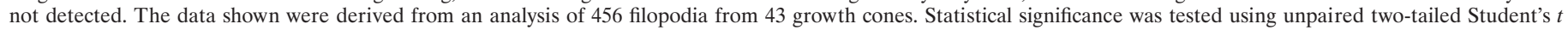
test; the asterisk shows $p \leq 0.0001$ compared to laminin values in the same class.

extensively into small explants using tungsten needles. Approximately 20-30 explants were transferred in $200 \mu \mathrm{l}$ of medium into a $13 \mathrm{~mm}$ diameter center well of a $35 \mathrm{~mm}$ glass-bottomed Petri dish. Acid-washed glass substrates were prepared beforehand by coating them with polyornithine (Sigma, St. Louis, MO; $1 \mathrm{mg} / \mathrm{ml}$ in water) followed by laminin (Life Technologies; $100 \mu \mathrm{l} / \mathrm{ml}$ in $250 \mathrm{~mm}$ Tris/HCl buffer, $\mathrm{pH} 7.4$ ). Cultures were maintained at $37^{\circ} \mathrm{C}$ in $5 \% \mathrm{CO}_{2}$ for at least $2 \mathrm{hr}$ before recording.

To assess the role of selected cell surface molecules, the medium was exchanged $1 \mathrm{hr}$ before recording with pre-equilibrated medium containing a selected monoclonal antibody [HNK-1, which recognizes an epitope expressed on both DRG and Schwann cells; 1E8 which recognizes Po, the earliest known marker for Schwann cells (Bhattachyaryya et al., 1991; a gift of Eric Frank, University of Pittsburgh, Pittsburgh, PA); anti-fibronectin (Sigma; catalog \#F3648); or NCD-2 (200 $\mu \mathrm{g} / \mathrm{ml}$; a gift of G. B. Grunwald, Jefferson Medical College, Philadelphia, PA), which recognizes the $\mathrm{N}$ terminus of chick $N$-cadherin (Hatta and Takeichi, 1986)]. Cultures were also labeled with appropriate secondary antibodies to confirm that the primary antibody bound effectively at the concentrations applied (data not shown), using protocols as in Oakley and Tosney (1993).

To assess the role of G-proteins, pertussis toxin (PTX; $200 \mathrm{ng} / \mathrm{ml}$; Sigma) was added after cells had incubated for 1-2 hr. Cultures were incubated an additional $3 \mathrm{hr}$, and the medium was exchanged with fresh, pre-equilibrated, PTX-containing medium $15 \mathrm{~min}$ before recording. As negative controls, the ceramidase inhibitor oleoylethanolamine (100 or $50 \mathrm{~nm}$ ) or the phosphatidycholine-specific phospholipase $\mathrm{C}$ inhibitor tricyclodecan-9-yl-xantogenate potassium $(25 \mu \mathrm{g} / \mathrm{ml})$ were added; neither altered nor diminished the invariant response to contact with Schwann cells (data not shown). As a positive control, the PTX used was tested in an established assay where PTX reversed growth cone-neurite inhibition (C. Walker and R. Hume, unpublished observations).

Optical recording. Cultures were recorded on optical laser disk at 15 frames per minute as in Steketee and Tosney (1999). Potential interactions between sensory growth cones and non-neuronal cells from ganglia ("Schwann cells") were selected based on trajectory, morphology, and absence of interference from debris or other cells. Schwann cells were morphologically recognizable as highly motile and distinctive cells with large, rounded lamella at the leading edge, one or two consolidated cytoplasmic extensions at the trailing pole, and nuclei eccentric to the trailing edge. These morphological features predicted the direction of migration and facilitated selection of potential interactions. Schwann cells isolated from sciatic nerves or from dorsal or ventral roots elicited identical responses (data not shown). Growth cones were selected that made steady progress overall (albeit at different rates), without showing spontaneous collapse. No attempt was made to select growth cones of a particular size or rate of advance. For instance, growth cones were recorded that, before contact, ranged in surface area from 2.1 to 11.1 $\mu \mathrm{m}^{2}$, in complexity from 4 to 23 filopodia, and in speed from a slight withdrawal $(-2.2 \mu \mathrm{m} / \mathrm{min})$ to $4.3 \mu \mathrm{m} / \mathrm{min}$. Despite their diversity, all growth cones showed the same, invariant response to Schwann cell contact. To confirm purity, cultures were labeled with HNK-1 monoclonal antibody as in Oakley and Tosney (1993). HNK-1 brightly labels neural crest-derived sensory neurons and Schwann cells, but not potential contaminating populations such as sclerotome cells, vascular endothelia, or fibroblasts. A recording session ended when the growth cone ceased to contact the cell or after $35 \mathrm{~min}$.

Image analysis. To detect any invariant response to contact, stringent criteria are needed to distinguish contacting from noncontacting filopodia and to exclude ambiguous cases in which technical limitations would not allow clear determination as to whether or not contact has been made. Except for data in Table 1, the established concept of a "stable contact" was used, with twofold criteria that rested on retrospective analysis of recordings: filopodia were considered to be stably contacting the substrate or cell only if they straightened as though under tension and remained motionless and rigid for at least $1 \mathrm{~min}$. Stable filopodial contacts were analyzed during two time periods. "Precontact periods" were defined as periods before stable filopodial contact with the Schwann cell. During this period, all filopodia stably contacted laminin alone. "Postcontact periods" were defined as periods with stable filopodial contact, cells were considered to be interacting actively. During postcontact periods, filopodia were classified as "noncontacting" if they adhered to laminin and "contacting" if they adhered to Schwann cells. Veils were defined as lamellar projections that extended at least $2 \mu \mathrm{m}$ from the filopodial base (Steketee and Tosney, 1999). The time of veil initiation was defined as the time when such a veil is first detectable. The recorded session of each growth cone was considered to be one interaction, during 


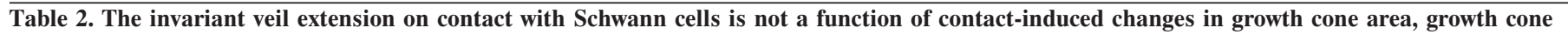
speed, or filopodial number

\begin{tabular}{|c|c|c|c|}
\hline & $\begin{array}{l}5 \text { min before contact: } \\
\text { mean } \pm \text { SD median, range }\end{array}$ & $\begin{array}{l}5 \text { min after contact: } \\
\text { mean } \pm \mathrm{SD} \text { median, range }\end{array}$ & $\begin{array}{l}10 \text { min after contact: } \\
\text { mean } \pm \text { SD median, range }\end{array}$ \\
\hline \multirow[t]{2}{*}{ Growth cone area, $\mu \mathrm{m}^{2}$} & $6.75 \pm 2.41$ & $8.23 \pm 3.10$ & $8.47 \pm 1.56^{*}$ \\
\hline & $7.2,2.1-11.1$ & $8.8,2.6-13.1$ & $8.7,5.5-11.9$ \\
\hline \multirow[t]{2}{*}{ Growth cone speed, $\mu \mathrm{m} / \mathrm{min}$} & $0.92 \pm 1.22$ & $1.23 \pm 0.77$ & $1.20 \pm 1.70$ \\
\hline & $0.5,-0.23-4.30$ & $1.0,0.12-2.47$ & $1.3,-0.20-4.50$ \\
\hline \multirow[t]{2}{*}{ Number of filopodia per growth cone } & $11.06 \pm 5.84$ & $10.28 \pm 4.5$ & $11.14 \pm 4.4$ \\
\hline & $8,4-23$ & $9,3-17$ & $11,2-15$ \\
\hline
\end{tabular}

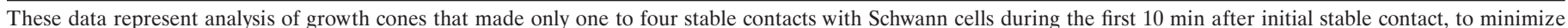

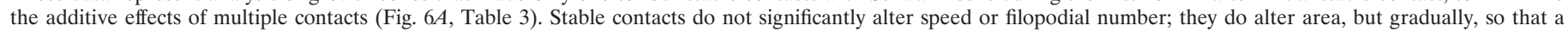

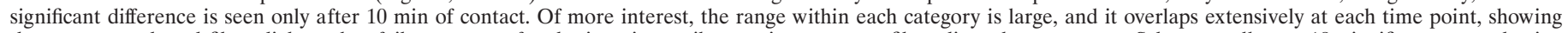

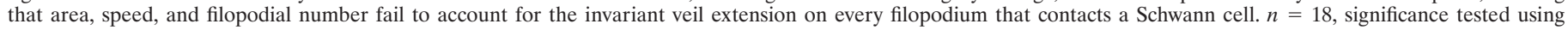
Student's unpaired $t$ test; asterisk shows a difference between 5 min precontact and 10 min postcontact at $p<0.03$.

which many individual filopodial contacts were made, both with the laminin substrate and the Schwann cell.

To determine if more transient or less stable contacts also induced veils on contact with Schwann cells (Table 1), veil extension and the duration of contact were assessed in various types of filopodial contact, based on two criteria: (1) whether the filopodial tips were moving or stationary; stationary tips may, with some ambiguity, be inferred to be contacting the substrate; or (2) whether the filopodial shafts remained flexible or became rigid on contact. The types of contact were: (1) noncontacting, in which filopodial tips moved constantly, without hesitation, showing a lack of adhesion, (2) "hesitating", in which filopodial tips appeared to remain stationary for $0.1-0.9 \mathrm{~min}$, suggesting adhesion, but the shaft failed to straighten, (3) "transient" contacts in which the filopodial tip was static for $0.1-0.9 \mathrm{~min}$ and the shaft straightened on contact, and (4) stable contacts, in which the tip was unmoving for $\geq 1.0 \mathrm{~min}$ and the shaft straightened on contact. We also searched for contacts $\geq 1.0 \mathrm{~min}$ in which the shaft did not straighten on contact, but found none. Filopodia $(n=$ 456) were analyzed on contacting (Schwann cell substrate) and noncontacting (laminin substrate) sides of 43 growth cones during the first 15 min of postcontact interactions.

To determine if contact-induced changes in growth cone area, growth cone speed, or filopodial number could account for the local change in veil dynamics on contact with Schwann cells, these characteristics were measured in 18 growth cones 5 min before and 5 and 10 min after the initial stable contact (Table 2). Interactions were selected in which growth cones made only 1-4 stable contacts with Schwann cells during the first $10 \mathrm{~min}$ after initial contact, to let us distinguish the effects of single contacts from the possible additive effects of multiple contacts. For area measurements, the phase-light central portions of growth cones with the peripheral spread regions and the veils, but excluding filopodia and phase-dark consolidated portions, were traced onscreen and the area was calculated using functions of the Image-1/Metamorph program (Universal Imaging). Speeds of advance were calculated over a 5 min period centered on each time point. Filopodia were counted manually at each time point and examined to determine if they did or did not extend veils within $3.5 \mathrm{~min}$ of stable contact. To determine if veil activity increases systematically with growth cone area, the extension of veils on filopodia contacting laminin during the initial $15 \mathrm{~min}$ postcontact interval was assessed (see Fig. 5). To examine integration of responses, this population was also analyzed to determine if an overall behavioral response to contact, an increase in growth cone area, correlated with the number of stably contacting filopodia (Table 3).

To examine the temporal metrics of veil extension on filopodia making stable contacts, the time from initial stable contact to either veil initiation or to filopodial detachment without veil initiation was determined on laminin and Schwann cell substrates for all filopodia that were present during the first 15 min after initial contact with Schwann cells (see Fig. 3).

To compare normal and treated cultures, veil extension, veil stabilization, growth cone area, and filopodia number were measured in both precontact and postcontact intervals in untreated and in NCD-2-treated and PTX-treated cultures (see Figs. 2, 4, 6). In HNK-1, 1E8, and fibronectin-treated cultures, veil induction and stabilization were analyzed, and in oleoylethanolamine and tricyclodecan-9-yl-xantogenatetreated cultures, veil induction was analyzed. To detect changes in veil extension on contact, all veils were counted during entire precontact and

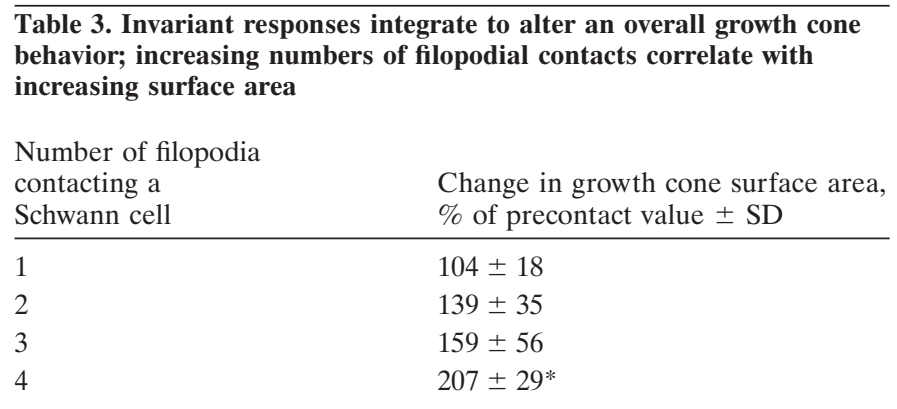

Increasing numbers of filopodial contacts accord with increasing surface area, suggesting integration of discrete responses. These data represent analyses of growth cones that made only one to four contacts total with a Schwann cell during the first 10 min of interaction (unlike those growth cones in Fig. $6 \mathrm{~A}$ that gradually made extensive contact, resulting in significant increases in growth cone area over time). Here, the average maximum change in growth cone area over the first $10 \mathrm{~min}$ of contact is expressed as a percentage of the area measured $5 \mathrm{~min}$ before contact. $n=18$ growth cones; values for one and four filopodia are significantly different at ${ }^{*} p<0.5$, using Student's unpaired $t$ test.

postcontact periods. In all untreated interactions, we noticed that $100 \%$ of filopodia stably contacting Schwann cells extended veils within $3.5 \mathrm{~min}$ of contact. We therefore calculated the percentage of precontact, postcontact, and noncontacting filopodia that extended veils within the same period. To determine the stability of veils, the history of every veil was noted as either a "retract" (veil retracted and disappeared) or a "fill" (veil was stable and later engorged). To determine whether veil stabilization after contact was general (throughout the growth cone) or focal (restricted to contacting filopodia alone), each veil was also classified as extending along either "contacting" or "noncontacting" filopodia. To measure an overall consequence of veil activities, growth cone surface area was measured as above once per minute, and values were normalized for comparisons. To detect contact-dependent changes in filopodial extension, filopodia were counted once per minute throughout each interaction.

For statistical comparisons, repeated measures ANOVAs were used to first determine that the contact state of the growth cone affected veil induction or stabilization within each treatment group. Repeated measures ANOVAs also showed whether the type of treatment had a significant effect on veil induction and stabilization. It was then possible to make statistical comparisons within and between individual groups using paired $t$ tests. For example, the "postcontact-contacting" group was compared to the "precontact" group in the untreated condition. Paired $t$ tests were also used to compare precontact to postcontact growth cone area, growth rate, and filopodia number. To present data from growth cones of variable sizes and shapes, the quantitative measurements of growth cone area and filopodia number were normalized by expressing values as a percentage of the maximum value. On graphs, error bars represent SEM; in tables and text, means and SD are reported. 


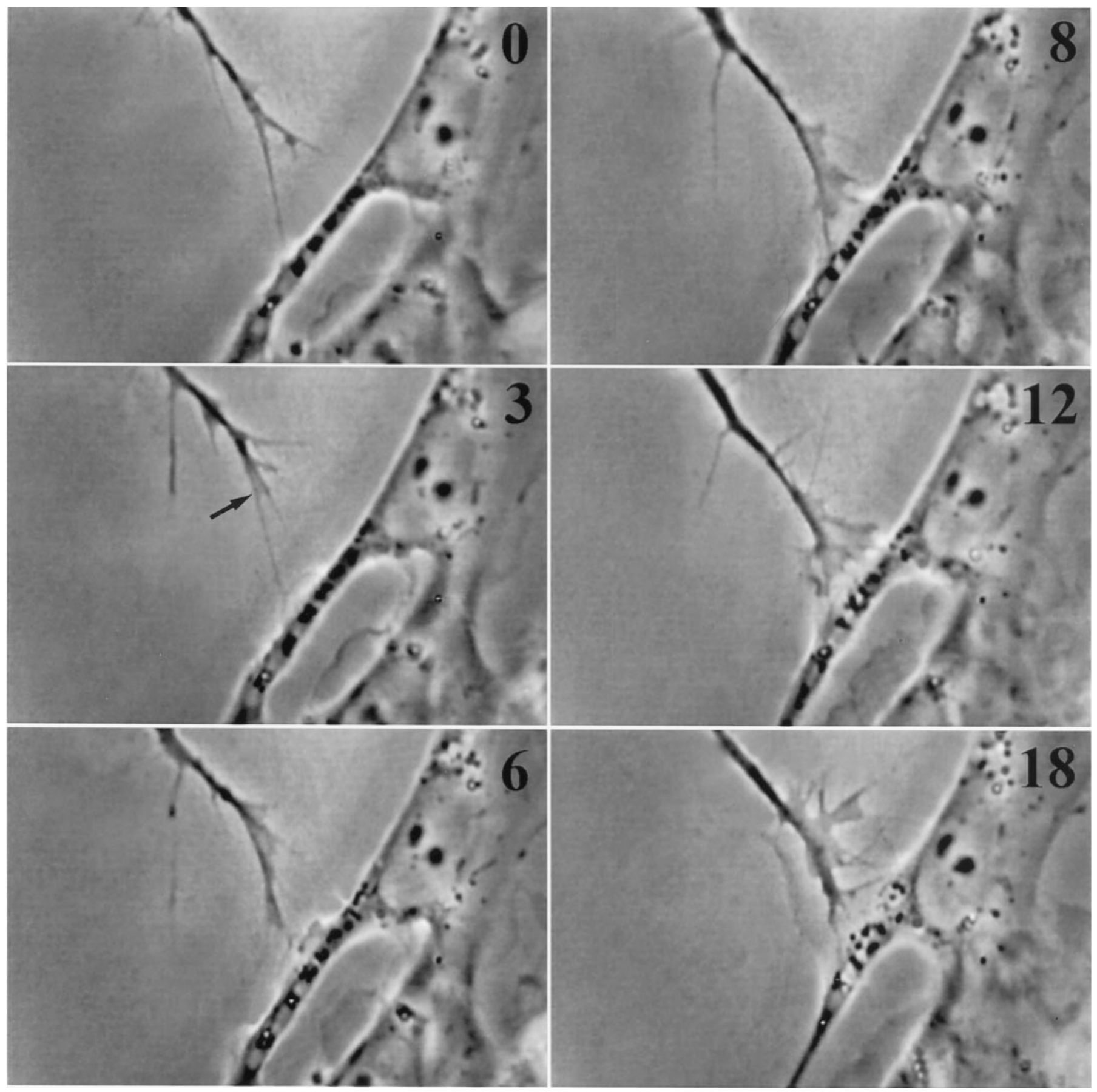

Figure 1. Stable filopodial contact with a Schwann cell stimulates an invariant response. Frames shown in this and subsequent micrographs indicate elapsed time since initial stable contact in minutes at top right. Note the rapid formation of a veil (arrow) within 3 min of initial contact. As more filopodia contact, they too induce local veil extension. Veils are relatively stable and accumulate to enlarge the growth cone even before it moves onto the cell (see also Fig. $6 \mathrm{~A}$ ). The growth cone advances along the regions of greatest protrusive activity, as veils fill with cytoplasm and then consolidate to form neurite. This Schwann cell also responded to contact by extending a veil (3 min), which later spread under the growth cone (18 min).

\section{RESULTS}

\section{Growth cone response to Schwann cells}

As easily seen in recordings, growth cone contact with a Schwann cell robustly stimulated veil extension (Fig. 1). During the precontact period, a filopodium often waved over the Schwann cell, but eventually its tip would adhere to the cell, and the filopodium would stop moving and straighten as if under tension (Fig. 1, 0 min); such filopodia were considered to be making stable con- tacts. The stable contact of just one filopodial tip, for remarkably brief periods of time, initiated a sequence of distinctive events: an induction of veil extension, a stabilization of veils, and a consequent growth cone enlargement and advance onto the Schwann cell.

The first event is discrete and invariant: a veil always extended along a contacting filopodium (Fig. 1, 3 min). This initial response to stable contact was rapid, reproducible, and confined solely to 
contacting filopodia. The veils extended swiftly after contact. Remarkably, in many cases the response was essentially immediate, and veils extended within the sampling interval of $4 \mathrm{sec}$; we saw contact in one frame and a veil in the next. Minimal contact, for a minimal duration, was required to elicit veil extension. A single filopodium sufficed, even though veils are commonly envisioned as extending between two filopodia. Moreover, this veil extension is not a mere spreading onto a more adhesive substratum, but a response to some signal from the filopodial tip. Veil extension was induced even when the entire growth cone lay on laminin and the filopodium contacted the cell only at its tip (Fig. 1). The response cannot be attributable to a simple maximizing of direct adhesion.

The veil extension stimulated by stable contact was confined to those filopodia that actually contacted the Schwann cell and was impressively invariant (Fig. 2A). Every filopodium contacting a Schwann cell extended a veil within $3.5 \mathrm{~min}$, whereas filopodia stably contacting laminin, before or after the Schwann cell interaction commenced, extended veils randomly and much less frequently. During their first $3.5 \mathrm{~min}$ of contacting the laminin substratum, $37 \%$ of filopodia extended veils, and although many filopodia adhered for longer periods, many detached without extending veils at all (Figs. $2 A, 3$ ). Against this modest baseline of veil extension, it is impressive that veils extended on every filopodium that contacted a Schwann cell. Indeed, $>400$ additional filopodial contacts observed by four independent observers have failed to reveal a single contrary case (M. Polinsky, K. Balazovich, M. Steketee, and L. Foa, unpublished observations).

The temporal metrics of veil extension also indicates that veils on filopodia contacting Schwann cells are actively induced. On stable contact with Schwann cells, all veils initiated rapidly (mean, $0.81 \mathrm{~min} \pm 0.69$ ), within a restricted temporal period (range, 0.1-2.7 $\mathrm{min}$ ), and the distribution of initiations was skewed toward early values (Fig. 3A). All filopodia extended veils before detaching. In contrast, on filopodia stably contacting laminin, veils initiated significantly later (mean, $2.48 \pm 2.37 ; p<0.0001$ ), over a larger temporal period (range, 0.1-19.8 min), and initiations were more evenly distributed (Fig. $3 B$ ). Moreover, many filopodia stably contacting laminin detached without having extended veils, even those that had remained attached for long periods (range, 0.1-21.5 min; Fig. 3C).

The invariant veil extension on contact with Schwann cells is not simply a function of the type or duration of contact (Table 1). The duration of stable contacts (defined as those $>1.0$ min with the shaft straightening on contact) did not differ with substrate. Likewise, the duration of transient contacts $(<1.0$ min with shaft straightening) did not differ with substrate. Therefore, a longer duration of contact with Schwann cells cannot explain the higher incidence of veil extension. Moreover, although the $n$ is small, filopodia making even very brief contacts $(<1.0 \mathrm{~min})$ with Schwann cells all extended veils before detaching. The small number of such brief contacts seen could be attributable to difficulties in detecting them on Schwann cells. The difficulty is particularly acute when using only a single criterion, tip-stasis, which is very difficult to discern against the background of the phase-dark Schwann cell. Indeed, in "hesitating contacts" $(<1.0$ min without shaft-straightening) Schwann cell contacts of $<0.8$ min were not detected. However, relatively few contacts were detected on Schwann cells even when using shaft straightening as a criterion as well, in "transient contacts". Another possible explanation for the small number of brief contacts detected and the significant difference in the duration of Schwann cell contacts



\section{B. Veil stabilization}

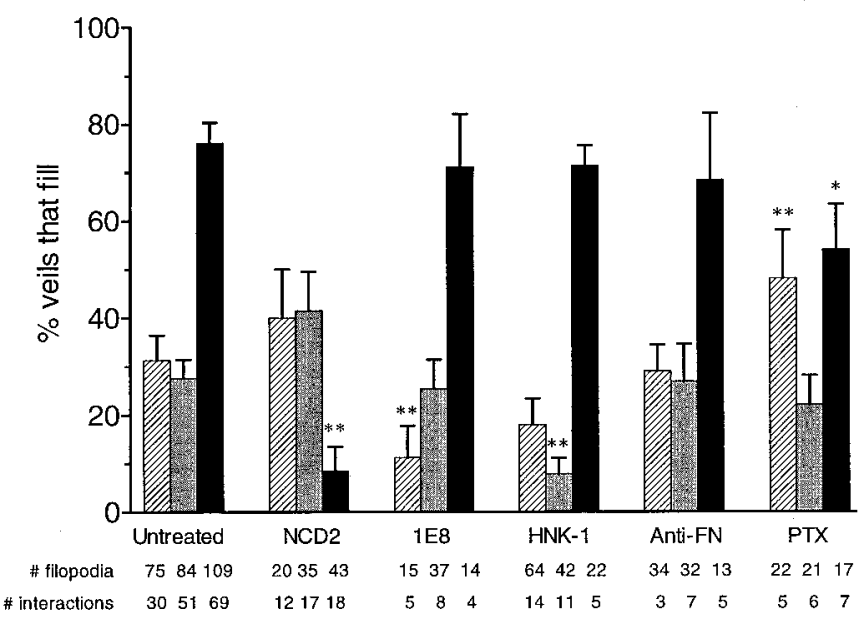

Figure 2. Responses to stable contact. Veil extension $(A)$ and stabilization $(B)$ are both significantly stimulated by stable contact in untreated cells. In $A$, the entries for filopodia contacting Schwann cells in untreated, $1 \mathrm{E} 8, \mathrm{HNK}-1$, or anti-fibronectin conditions lack error bars because every single filopodium stably contacting Schwann cells showed veil induction, without exception. In the untreated conditions, veil extension on filopodia contacting Schwann cells differs from both the precontacting and the noncontacting values at $* * p<0.0001$. This response is invariant. During postcontact periods, comparing activities on contacting and noncontacting filopodia in untreated cells documents that the stimulation is local, confined to filopodia contacting Schwann cells. The effects on veil tension and stabilization are both abolished with either a blocking antibody to $N$-cadherin $(N C D-2)$ or pertussis toxin $(P T X)$. The PTX elimination of the contact-induced veil extension was detectable and significant despite the PTX stimulation of veil stability on laminin before contact. Likewise, veil induction is unaltered by $1 \mathrm{E} 8, \mathrm{HNK}-1$, and anti-fibronectin antibodies, despite their differential effects on other motile activities: the antifibronectin alters veil extension on laminin before contact, 1E8 alters stabilization before cell contact, and HNK-1 alters stabilization after contact but only on noncontacting filopodia. Error bars indicate SEM. $* p<0.05 ; * *<0.01$ compared to the corresponding untreated values.

in the hesitating class is that many initial contacts with Schwann cells may transform into longer-lived stable contacts. Schwann cell contact may stimulate shaft straightening and stability. Shaft straightening does appear to be a general concomitant of all longer-lived contacts, even those on laminin, because the "hesitating" contacts in which shafts fail to straighten were generally 


\section{A. Schwann cells: veil initiation}

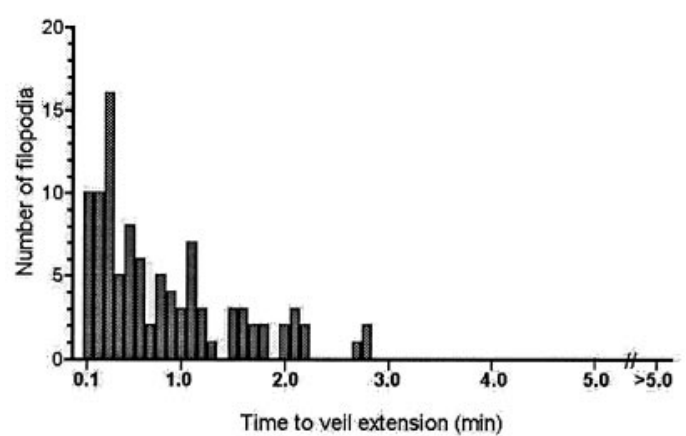

B. Laminin: veil initiation

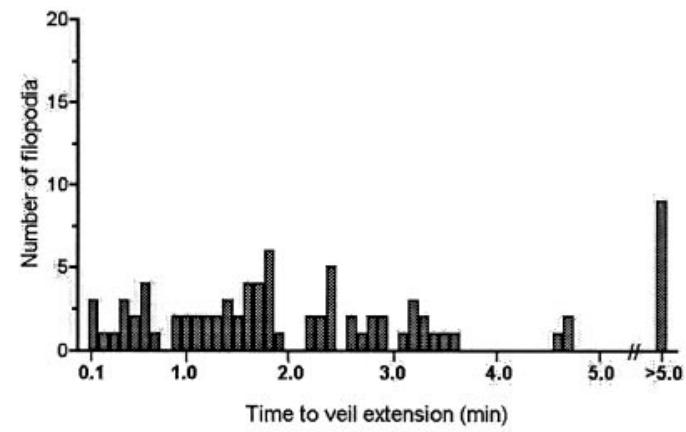

C. Laminin: detached without veil initiation

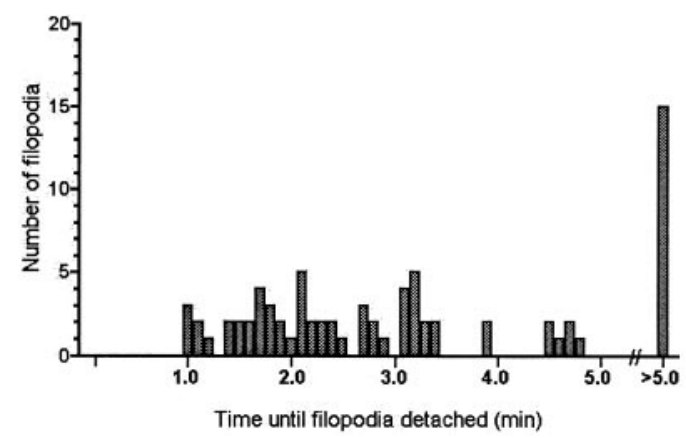

Figure 3. Temporal metrics of veil extension. A, On filopodia making stable contact with Schwann cells, veil initiation is skewed toward early times. All veils extend rapidly, within 3.5 min of contact (mean, $0.81 \pm$ 0.69 ; range, 0.1-2.7 $\mathrm{min}$ ), and before the filopodium detaches. $B$, In contrast, on filopodia from the same growth cones that are stably contacting laminin, veil initiation is not so temporally skewed. Many veils initiate within the first $3.5 \mathrm{~min}$, but in a more even distribution, and the first veil may not extend for many minutes (mean, $2.48 \pm 2.37$; range, 0.1-19.8 min). $C$, Moreover, many filopodia stably contacting laminin detach without having extended veils, despite long durations of contact (range, 1.0-21.5 min). Data reflect analysis of 80 stable contacts with laminin and 100 stable contacts with Schwann cells that were present during the first 15 min of contact, on 34 growth cones. Mean values for initiation in $A$ and $B$ are significantly different $(p<0.0001)$, using the two-tailed unpaired nonparametric Student's $t$ test.

very brief on laminin (mean, $0.21 \pm 0.12 \mathrm{~min}$ ) and were not detected at $>0.6 \mathrm{~min}$. Furthermore, contacts longer than $1.0 \mathrm{~min}$ without shaft straightening were so rare that they are absent from this data set. Clearly however, stable contacts are a significant proportion of all contacts made with the Schwann cell. Veil extension on contacting filopodia is not, therefore, some irrelevant side effect pertinent only to a minor class of contacts.

The rapid veil response is also clearly not a consequence of

\section{A. untreated}

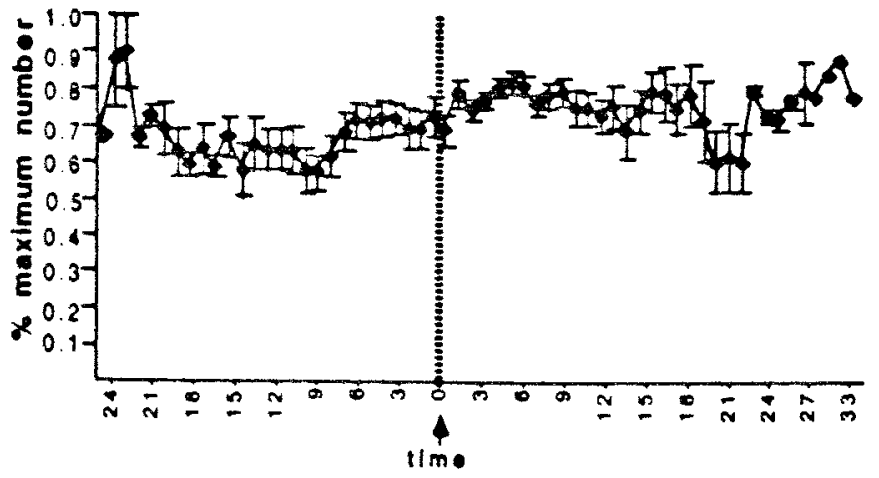

B. antl $N \cdot c a d h e r l n$ antibody

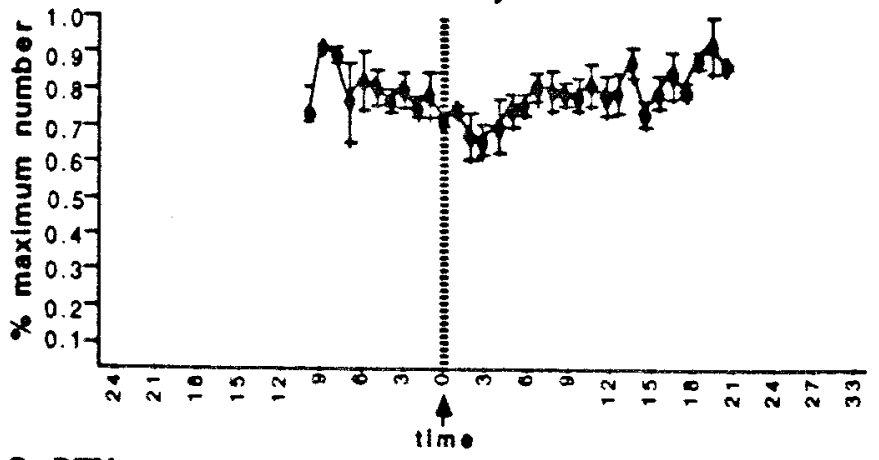

C. PTX

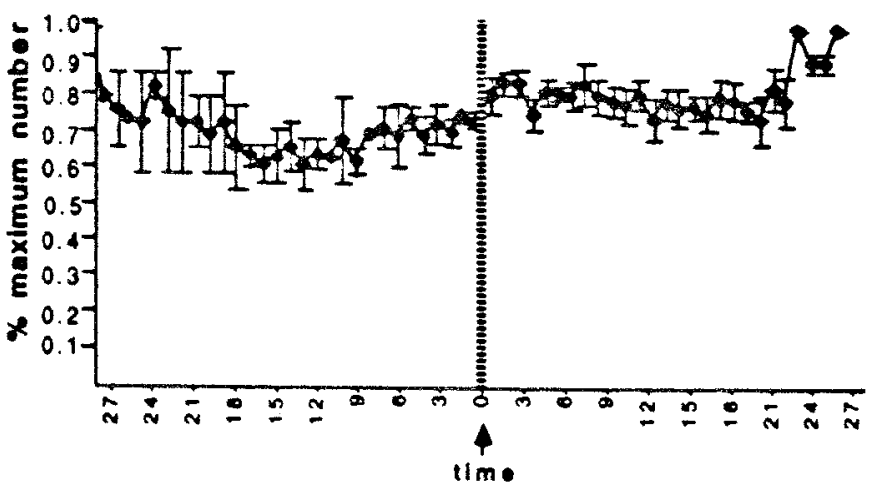

Figure 4. Filopodial extension. Contact (time 0 ) does not alter the numbers of filopodia extended in untreated or treated cells. $(A, n=18$ interactions; $B, C, n=7$ for each treatment.) In $B$, interactions were followed for a shorter period.

changes in other growth cone metrics or some biased selection for growth cones with particular features. Every filopodial contact with Schwann cells induced veil extension, regardless of the fact that the range of sizes, complexity, and rates of advance among growth cones were quite diverse (Table 2). The invariant veil extension is not attributable simply to an increased protrusion of all processes, because the extension of filopodia was essentially unchanged (Fig. 4A, Table 2). Growth cone size does increase after stable contact (below), but the increase is gradual, variable, and later than the first invariant responses. In addition, contact does not stimulate veils simply because the contact enlarged the growth cone, and larger growth cones tend to extend more veils. Even on large growth cones, the veiling activity on individual filopodia remains a local function of the substrate contacted. Veil extension is unrelated to growth cone area. Each growth cone 


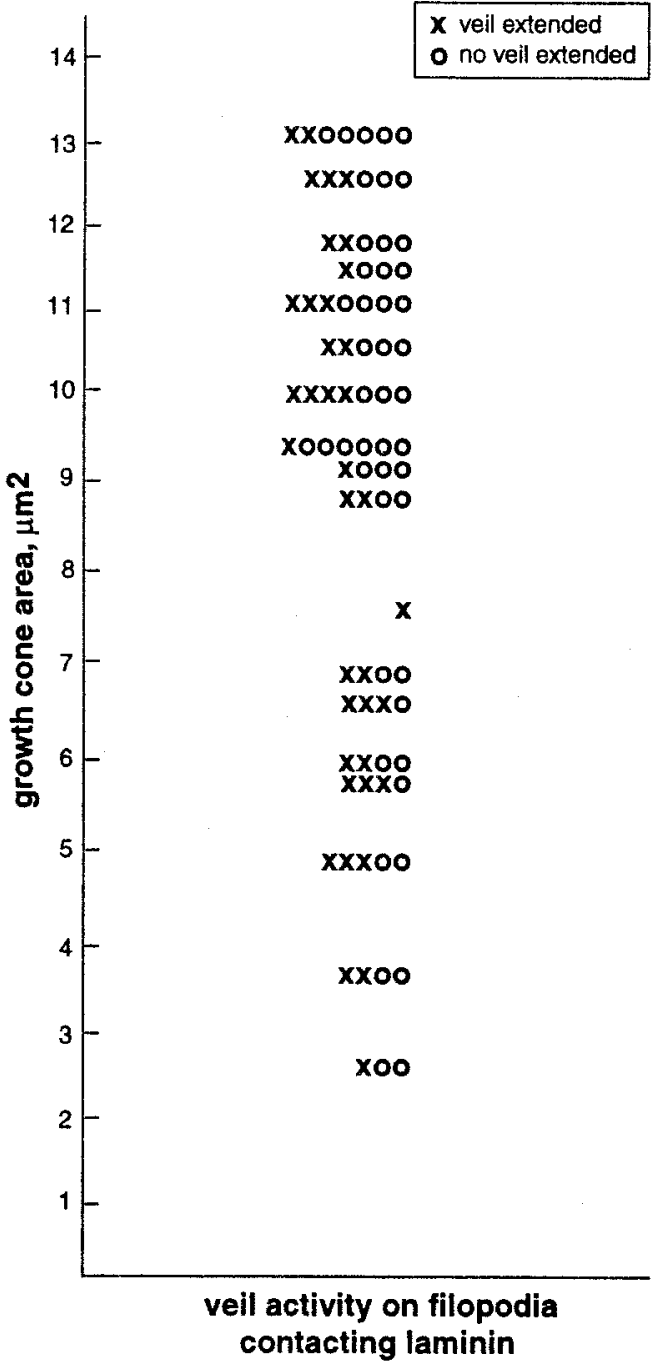

Figure 5. Veil activity fails to correlate with growth cone area. Ten minutes after the initial stable contact with a Schwann cell, the areas of growth cones were measured, and those filopodia making stable contacts with laminin were recorded as extending or failing to extend a veil within 3.5 min of contact. Each horizontal line portrays activity on a single growth cone $(n=18$ growth cones, 85 filopodia). In individual growth cones, filopodia were in both classes, extending and failing to extend veils, unlike those filopodia on the same growth cones that were directly contacting the cell (45 filopodia), which always extended veils. Thus, veil extension does not vary systematically with growth cone area, but is a property of the substrate contacted.

contacting a Schwann cell, regardless of its size, makes stable contacts with laminin that both do, and do not, extend veils (Fig. 5). Increases in growth cone area are therefore insufficient to account for the dramatically increased local veil extension on filopodia contacting the Schwann cell.

Because rapid veil extension characterizes every filopodial contact with Schwann cells, we consider the veils to be invariably induced by contact, and therefore call the veil induction the "invariant response."

In addition to inducing veil extension, stable contact also locally increases the probability that the site of induced veil extension will engorge with cytoplasm, a quality we termed "veil stabilization." Stabilization was assessed by following the full lifetime of veils. After protrusion, a veil either retracted and disappeared or it stabilized and subsequently "filled" with cytoplasm, thereby advancing the growth cone. Stability was markedly enhanced by stable filopodial contact with a Schwann cell. In repeating cycles, veils extended, remained in an extended state, and then eventually filled (Fig. 1); $78 \%$ of veils that had extended along contacting filopodia filled (Fig. 2B). In marked contrast, veils extending along those filopodia in precontact intervals had just the opposite tendency and generally retracted. The stabilization was local rather than attributable to an overall change in growth cone dynamics on contact because the low fill rate at noncontact sites was comparable to the precontact rate.

Two overall growth cone behaviors commonly alter as a consequence of the locally enhanced veil extension and stability that was reiterated with each stable contact, producing an additive effect. First, when multiple filopodia contacted the Schwann cell, growth cone area progressively increased, beginning within the first minute after contact (Fig. 6A). The increase in area correlated temporally with the cumulative enhancement of veil extension and stabilization, which was typically obvious within the first 1.5 min of contact. After 10-15 min of contact, growth cone areas had approximately doubled. Importantly, the enlargement of growth cones was not attributable to direct spreading along the surface of the cell, because it was visible when the only contact with the cell was via filopodia; instead, the growth cone enlargement was mediated by an accumulated effect of locally altered protrusive activity. Repeated cycles of veil extension and stabilization cause the growth cone to extend and retain more veils and thus to enlarge and become much more lamellar. Enlargement was usually obvious even before the growth cone body had advanced onto the cell (Fig. 1).

The increase in growth cone size appears to be a consequence of integrating individual discrete responses. Integration was assessed by analyzing interactions in which growth cones made only one to four stable filopodial contacts with a Schwann cell during the first 10 min of contact. The numbers of total contacts during this period increase in rough concert with the average maximum increases in surface area, doubling when four contacts were established (Table 3). These observations are in accord with the notion that overall growth cone behaviors result from integration of multiple signals (McCobb et al., 1988; Strittmatter and Fishman, 1991; Erskine and McCaig, 1997; Ming et al., 1997; Song et al., 1997; Wang and Zheng, 1998). They extend this idea by suggesting that integration might emerge from an addition of very discrete responses.

A second consequence of reiterated veil induction and stabilization is directional growth cone migration. Trajectory, an overall behavioral response, is determined by regional differences in protrusive activity; a prerequisite for turning is a local change in motile activities. Growth cones advance preferentially in regions where veils extend and engorge most vigorously. Because stable contact dramatically enhanced these components of motility, growth cones preferentially advanced at contact sites and consequently onto the Schwann cell. The spatial containment of the response to contact sites was necessary for turning behavior and, by implication, for navigation.

\section{Schwann cell response to growth cones}

Stable filopodial contact sometimes stimulated a focal extension from the Schwann cell, a small rounded lamella that extended from the contacted site and progressively enlarged with persistent contact (Fig. 1). In these cases, growth cones and Schwann cells mutually stimulated each other's protrusive activity. However, 

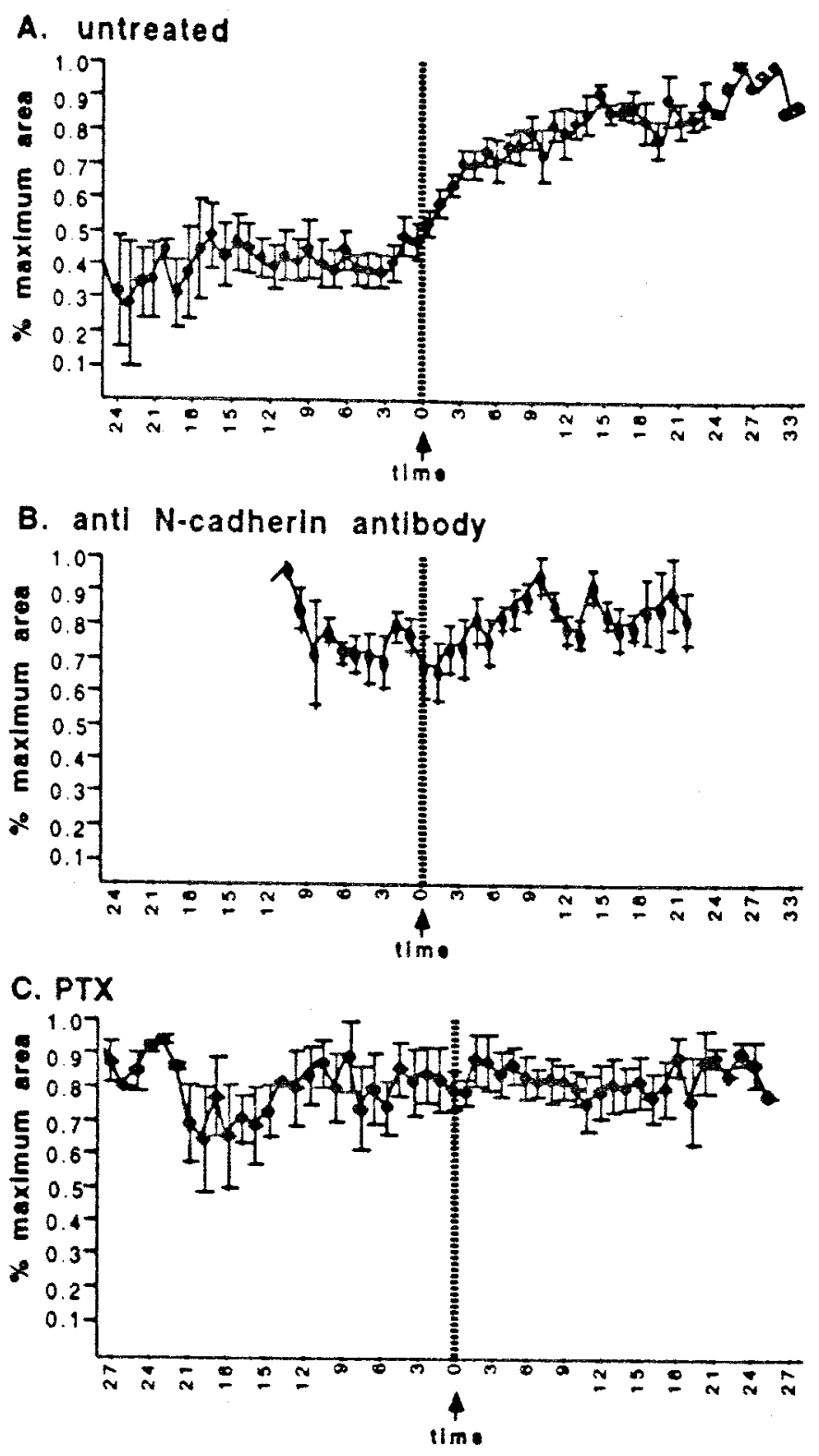

Figure 6. Growth cone area. Area increases after stable contact (at time 0 ) with untreated cells ( $A, n=18$ interactions), but fails to change in treated cultures $(B, C, n=7$ for each treatment). In $B$ interactions were followed for a shorter period. All growth cones analyzed here ultimately contacted the Schwann cell with multiple filopodia during the recorded interaction.

the Schwann cell response was relatively rare $(\sim 20 \%$ responded $)$ and seldom as rapid as the growth cone response. Despite their common origin in the neural crest, the sensory neuron and Schwann cell show diverse responses to contact, even at this early developmental stage.

\section{Interactions during $\mathbf{N}$-cadherin blockade}

Blocking the function of $N$-cadherin abolished the invariant response to stable contact with Schwann cells. Treatment with NCD-2 eliminated the local, contact-mediated induction of veil extension. Filopodia still adhered to the cell, and filopodial contact even when multiple and prolonged, failed to stimulate veil extension (Fig. 7). Despite protracted contact (>20 min), veils extended on contacting filopodia at a rate comparable to that in the precontact period and significantly less than that in untreated cells (Fig. 2A). In NCD-2-treated cells, those veils that did form generally took longer to form and required more extensive contact with the Schwann cell. The absence of induction contrasted markedly with the untreated cells, in which even single contacts briskly enhanced veil extension. Blocking $N$-cadherin also abolished veil stabilization on contact, reducing it to below the baseline value on laminin (Fig. $2 B$ ). Veils extending along contacting filopodia were relatively unstable and retracted $90 \%$ of the time, contrasting with the stability of veils in the untreated condition. Contact under $\mathrm{N}$-cadherin blockade was insufficient to stimulate preferential engorgement.

In the absence of the invariant response, stable contact seldom altered growth cone behavior. First, growth cones did not enlarge after contact, even when multiple filopodia made prolonged contact with a Schwann cell, contrasting with the doubling of area in untreated cells (Fig. 6A,B). As in untreated conditions, the number of filopodia extended was unaffected (Fig. 4B). Second, as veils extended and stabilized randomly, the growth cones tended to migrate along their precontact trajectory rather than preferentially advancing toward contact sites. Some even turned away from the cell.

Observations of precontact motility served as an internal control. NCD-2 had no effect on precontact morphology or motility. Growth cones were similar in size and shape and possessed similar numbers of filopodia (Figs. 4, 7). Likewise, Schwann cells remained highly motile and retained normal morphological features.

In contrast, antibodies that bound to other epitopes on the surface of the Schwann cell and or/growth cone failed to even diminish veil induction (Fig. $2 A$ ). Veils extended on $100 \%$ of the filopodia stably contacting Schwann cells treated with antibodies to fibronectin, Po (antibody 1E8), or the HNK-1 epitope. Neither the antibody presence on the cell surface, nor disrupting adhesion through such molecules, sufficed to alter the invariant response. The retained induction of veils is the more striking in that each antibody did affect motile behavior in other respects (Fig. 2A,B). $1 \mathrm{E} 8$ diminished veil stability in precontact periods; HNK-1 diminished veil stability in postcontact periods but only on laminin; anti-fibronectin increased veil extension in precontact periods. Such effects can be discriminated from those relevant to the guidance interaction by focusing on the invariant response itself. Inhibiting a signaling function essential to the invariant response returns veil extension to baseline, so that the invariant response is abolished. Inhibiting other signaling systems may alter other aspects of motility, but failed to even modify the invariant response. Signaling systems likely play more than one role in motility, so that dissecting out discrete and relevant effects has been problematic. However, focusing on a local, invariant response can allow discrimination of causal relations.

\section{Interactions during G-protein blockade}

Similarly, the influence of PTX on the contact-mediated induction could be easily discriminated from its effects on the baseline motile behavior, using the spatiotemporal criterion of stable cell contact. PTX did not grossly alter motility in that growth cones and Schwann cells were indistinguishable morphologically from untreated cells (compare Figs. 1, 7), but it did have one notable effect on motility on laminin: it increased veil stabilization in precontact periods (Fig. 2B). However, because the invariant response is directly associated with stable contact, the effect that was directly relevant to the guiding interaction could be discrim- 

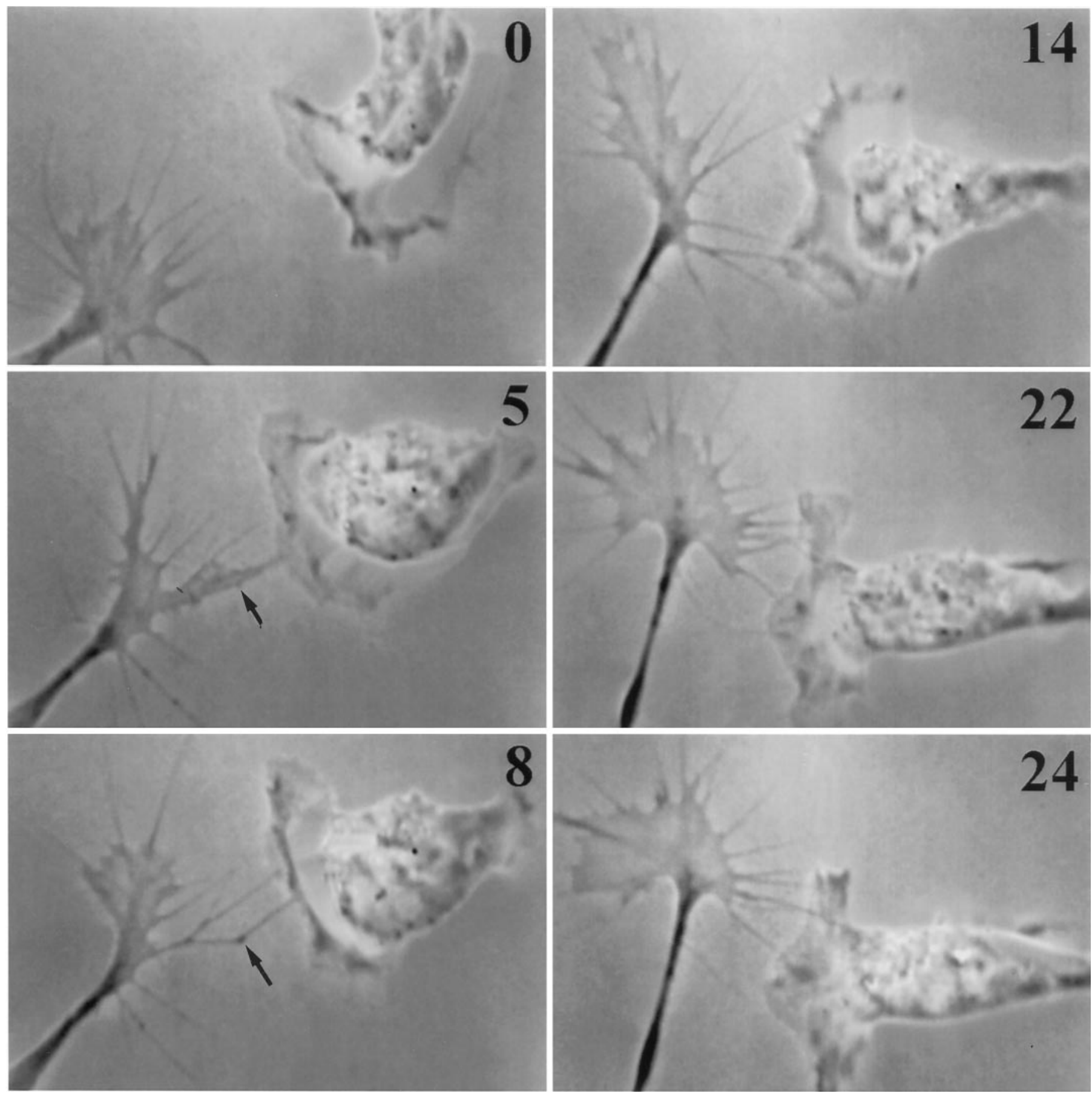

Figure 7. Blocking $N$-cadherin function blocks the invariant response. In the presence of blocking antibody NCD-2, stable contact fails to stimulate veil extension. Veils seldom form on contacting filopodia, and when they do form they are short-lived (arrows at 5 and 8 min). Note that multiple stable contacts fail to stimulate veil extension. The growth cone advances in the direction of its most robust protrusive activity. This Schwann cell retains some spreading response to contact: its leading edge initially faces perpendicular to the oncoming growth cone but reorients toward the contact site.

inated by examining the invariant response itself. The discreteness of the invariant response can be used as a discriminatory tool to distinguish how experimental treatments affect specific responses, even when the treatment alters some aspects of baseline motility.

PTX eliminated the contact-mediated induction of veil extension (Fig. 8); after initial contact, veil extension on stably contacting filopodia was reduced to baseline levels (Fig. 2A). Despite contact that was prolonged ( $>25 \mathrm{~min}$ ) and extensive (as much as the entire leading edge of the growth cone), contacting filopodia failed to extend veils any more efficiently than noncontacting or precontact filopodia. In addition, PTX significantly diminished the contact-mediated veil stabilization (Fig. 2B), but did not reduce it to a baseline value, suggesting that veil induction and veil stabilization may be separable consequences of stable contact. In the absence of specific induction on contact, the contact- 

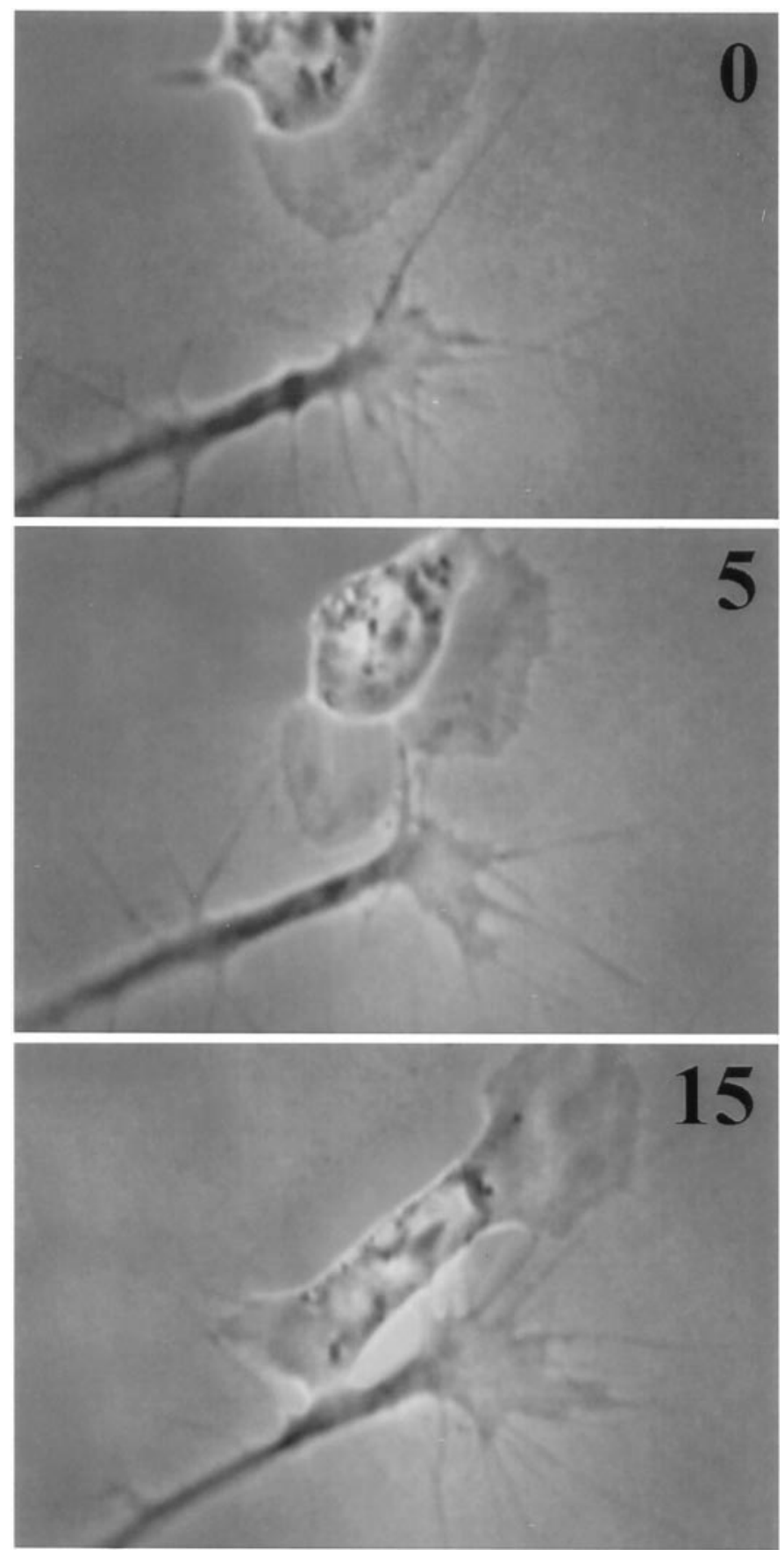

Figure 8. Pertussis toxin blocks the invariant response. In the presence of pertussis toxin, stable contact fails to induce veil extension. The growth cone proceeds along its previous course, parallel to the cell. The cell fails to spread toward the site of contact and instead becomes quiescent at the initial contact site.

associated changes in overall growth cone behavior were also greatly diminished. After contact, growth cones did not enlarge (Fig. 6C) and usually failed to advance onto the cell (Fig. 8). As in untreated conditions, the number of filopodia extended was unaffected (Fig. 4C).

\section{DISCUSSION}

This study identifies an invariant response, a stereotyped and reproducible consequence of stable filopodial contact that alters a highly discrete element of motility. Stable contact of sensory growth cone filopodia with Schwann cells invariably induces rapid veil extension. The invariant response is confined to the contacting filopodia. Even brief contacts and contacts confined to filopodial tips suffice for induction.

Invariant responses may be the common and most direct response to specific molecular interactions with the surfaces of guiding cells. Two other cell types have also been shown to induce discrete and invariant responses in both motor (Oakley and Tosney, 1993) and sensory (Steketee and Tosney, 1999) growth cones (Fig. 9): posterior sclerotome inhibits veil extension on stably contacting filopodia; anterior sclerotome stimulates protrusive activity throughout the growth cone and locally stimulates consolidation. All three invariant responses are relevant physiologically, because these cells guide axons in the embryo and/or during regeneration (Keynes and Stern, 1984; Carpenter and Holiday, 1986; Son and Thompson, 1995a,b). The filopodia likely act as long-distance sensors by ligand-receptor binding that modulates specific second messengers to alter cytoskeletal dynamics selectively. In accord with this posited relationship, the invariant response to Schwann cells is eliminated by blocking $N$-cadherin or inhibiting G-protein function.

These invariant responses are more typical sequela of contact than is the gross behavior, and reiterated cycles of each invariant response are needed to mediate a given gross behavior. In Schwann cell interactions, repeated cycles of veil induction can cause a growth cone to enlarge and turn. Likewise in posterior sclerotome interactions, repeated cycles of local inhibition are required to cause growth cones to stop or turn, and interactions with anterior sclerotome are often a protracted series of invariant responses (Oakley and Tosney, 1993).

Invariant responses must result from signaling rather than from adhesion alone. In Schwann cell interactions, a veil originates from the distant filopodial base and does not spread directly upon the cell. Even a consequence of repeated veil induction, growth cone enlargement, takes place while the contact is solely filopodial. Moreover, functionally blocking the homophilic binding molecule $N$-cadherin abolished the invariant response, but failed to abolish filopodial adhesion. The filopodia still adhered to the Schwann cell, which possesses many other adhesive molecules (Bixby et al., 1988; Seilheimer and Schachner, 1988; Bhattachyaryya et al., 1991). In contrast, antibodies to other surface molecules, fibronectin, Po, and the HNK-1 epitope, failed to modify the invariant response, despite their alteration of responses to laminin.

In this study we did not intend to characterize a signaling cascade fully, but rather to determine if blocking a likely signal could eliminate an invariant response. Results with PTX implicate a second messenger system involving G-proteins (Gilman, 1987; Strittmatter et al., 1990), but, more pertinent, they show that inhibiting specific signaling cascades can eliminate invariant responses. Such treatments discriminate direct effects on the most relevant guidance response, even when the treatment has indirect or nonspecific effects. Thus, for testing putative signaling molecules in guidance interactions, invariant responses can serve as a fine discriminating tool. An effect that is directly relevant to the guiding interaction can be identified by focusing on an invariant response directly.

\section{A model of growth cone guidance}

The most interesting feature of invariant responses to contact may be that they are indeed invariant. Every filopodium stably 


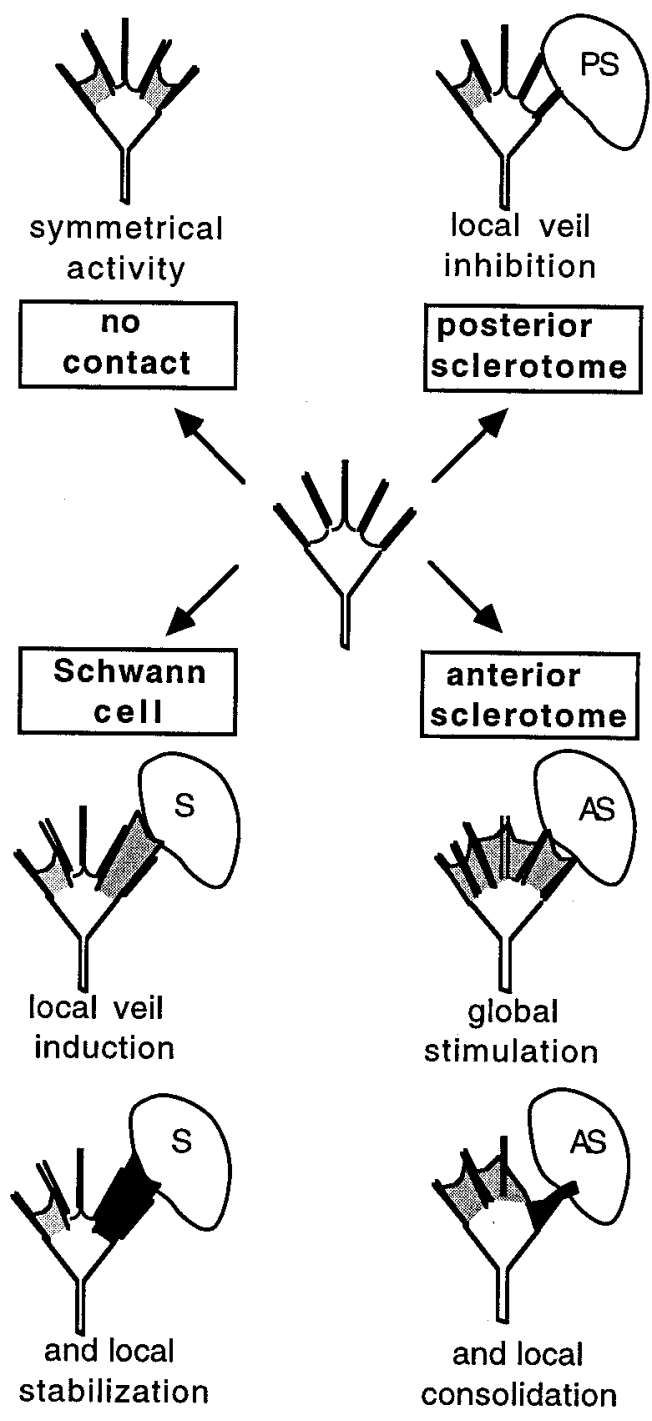

Figure 9. Schematic diagram of invariant responses. Motile activities are diagrammed for a growth cone on a homogeneous substratum (top left) or after stable filopodial contact with specific cell types (in clockwise order). Activity unbiased by contact is shown as symmetrical, with veils extending on both sides. Contact with a posterior sclerotome cell locally inhibits veil extension. The inhibition is a constant response; veils invariably fail to extend between contacting filopodia, even with repeated contacts, and extend again only when filopodial contact is lost. Contact with an anterior sclerotome cell stimulates extensions throughout the growth cone and then locally enhances consolidation of contacting processes in a manner overtly different than the veil stabilization by Schwann cells. The processes become motility-quiescent, thicken, and form a phase-dark region that rounds up to become neuritic. Contact with a Schwann cell locally induces veil extension. These veils are considered more stable because they seldom retract and they eventually engorge preferentially. Also see Oakley and Tosney (1993); Steketee and Tosney (1999).

contacting a given cell type elicits the identical response. The responses do not quench: repeated contacts also stimulate the identical response. In contrast, overall behavior varies as the invariant response is integrated with other factors, such as the angle or extent of contact, responses to additional cues, or the set-point for extension. For example, the invariant prohibition of veil extension by posterior sclerotome can beget three avoidance behaviors: a growth cone turns when only one side contacts, stops if all filopodia contact, or branches by forming veils at opposite, non- contacting sides. Because the invariant responses themselves are highly repeatable, they are likely to be direct physiological consequences of filopodial contact and major components of guidance mechanisms.

The invariant responses have another property, discreteness, which may make them particularly valuable as guidance mechanisms. Each invariant response is impressively discrete. It does not affect extension or engorgement or consolidation generally: it affects a very precise subset of one activity. The Schwann cell response invariably affects veil extension without altering filopodial extension. Another response alters only the consolidation of a contacting filopodium without changing its lifetime or initial engorgement; a third alters the extension of veils down a filopodium without changing initiation of veils on the same filopodium (Steketee and Tosney, 1999). The effect is that cues have a constant, and very discrete, readout in terms of motile activity. Cues elicit discrete changes in overt motile behaviors, and often do so locally. The discrete response is vital for navigation; local prohibition or stimulation or consolidation causes turns in particular directions.

This discreteness may facilitate signal integration. The final trajectory of a growth cone depends on integrating the many positive and negative signals impinging on it simultaneously (McCobb et al., 1988; Strittmatter and Fishman, 1991; Erskine and McCaig, 1997; Ming et al., 1997; Song et al., 1997; Wang and Zheng, 1998). If cues elicit discrete and invariant responses, signals could be integrated more easily. Our work suggests how invariant responses can integrate to alter growth cone behavior (Steketee and Tosney, 1999). As the number of stable contacts with Schwann cells increases, so does the growth cone area. Likewise, unitary responses to the inhibitory cue are added across the growth cone according to the number and site of stable contacts to produce turning, stopping, or branching. A local invariant response can integrate even with an aspect of motility that characterizes the entire growth cone. Growth cones on laminin regulate their general level of extension about a set-point, but when stable contact with posterior sclerotome prohibits veil extension locally, they compensate by increasing extension at distant sites, thereby both maintaining their set-point and amplifying avoidance.

The discreteness of an invariant response does not limit its implications for guidance. Indeed, the very discreteness helps to explain complex behaviors such as why growth cones track alongside barriers of inhibitory cues instead of turning away from them entirely. Because only veil extension (not duration of adhesion) is altered by stable contact with posterior sclerotome, contacting filopodia both tether growth cones to the cell and simultaneously prevent travel onto it. Noncontacting filopodia still extend veils and impel the growth cone forward, in parallel with the sclerotome border.

Because they would offer discrete effects that can be integrated, invariant responses may be a common guidance feature. If cues usually act by eliciting such discrete responses, then there are a wealth of fine ways in which different cues could alter trajectories. Many discrete changes could take place in veil extension alone: a cue could cause a growth cone to turn right by invariably inhibiting veil extension, veil initiation, or veil stability on its left side, or by stimulating these features on the right. Similar scenarios can be built for filopodial extension, or engorgement or consolidation. Different mechanisms can underlie even changes in growth cone size. Growth cones enlarge on contacting both positive cellular cues but by different means: anterior sclerotome contacts increase 
the frequency of both veil and filopodial initiation across the growth cone; Schwann cell contacts increase the initiation and stability of veils locally. Different cues can operate by inducing different and very discrete changes in motility. Conversely, other neuronal types may respond to the same molecular signal with an identical, invariant response. For instance, retinal growth cones assume an enlarged, lamellar morphology on filopodial contact with $\mathrm{N}$-cadherin substrata (Burden-Gulley et al., 1995), a gross behavior consistent with the invariant response shown here.

Invariant responses may be prevalent, but they are detectable only when motile histories are analyzed in detail. In the few other cases where detailed motility (rather than just turning behavior per se) has been analyzed, responses were found that meet half of our definition, by showing a discrete change in motility. Filopodia contacting guidepost cells preferentially engorge (O'Connor et al., 1990; Myers and Bastiani, 1993). Some cues abolish the ability to extend locally (Fan and Raper, 1995); some cause selective pruning of filopodia (Burmeister and Goldberg, 1988; Stretavan and Reichardt, 1993); others locally alter how many filopodia extend (Myers and Bastiani, 1993). However, whether these responses are invariant has yet to be tested.

Finding discrete, invariant responses to three different cellular cues suggested this model for growth cone guidance. We propose that many guidance cues induce discrete and invariant alterations in motility. In other words, cues do not act simply to control whether actin polymerizes at the leading edge in some either-or fashion. Instead, the response is richer and more nuanced: each cue generates a constant read-out on a discrete element of motility itself. Different cues induce different discrete changes. Because they are discrete, these responses can integrate in a straightforward manner. We are testing this model by examining the detailed motility of grow th cones as they contact other cellular guidance cues and defined molecular substrates.

\section{REFERENCES}

Aletta JM, Greene LA (1988) Growth cone configuration and advance: a time-lapse study using video-enhanced differential interference contrast microscopy. J Neurosci 8:1425-1435.

Bentley D, Toroion-Raymond A (1986) Disoriented pathfinding by pioneer neurone growth cones deprived of filopodia by cytochalasin treatment. Nature 323:712-715.

Bhattachyaryya A, Frank E, Ratner N, Brackenbury R (1991) Po is an early marker of the Schwann cell lineage in chickens. Neuron 7:831-844.

Bixby JL, Lilien J, Reichardt LF (1988) Identification of the major proteins that promote neuronal process outgrowth on Schwann cells in vitro. J Cell Biol 107:353-361.

Bottenstein JE, Skaper SD, Varon SS, Sato GH (1980) Selective survival of neurons from chick embryo sensory ganglionic dissociates utilizing serum-free supplemented medium. Exp Cell Res 125:183-190.

Burden-Gulley SM, Payne HR, Lemmon V (1995) Growth cones are actively influenced by substrate-bound adhesion molecules. J Neurosci 15:4370-4381.

Burmeister DW, Goldberg DJ (1988) Micropruning: the mechanism of turning of Aplysia growth cones at substrate borders in vitro. J Neurosci 8:3151-3159.

Calof A, Lander AD (1991) Relationship between neuronal migration and cell-substratum adhesion: laminin and merosin promote olfactory neuronal migration but are anti-adhesive. Cell Biol 115:779-794.

Carpenter EM, Holiday M (1986) Defective innervation of chick limbs in the absence of presumptive Schwann cells. Dev Biol 150:144-159.

Caudy M, Bentley D (1986) Pioneer growth cone morphologies reveal proximal increases in substrate affinity within leg segments of grasshopper embryos. J Neurosci 6:264-279.

Erskine L, McCaig CD (1997) Integrated interactions between chondroitin sulfate proteoglycans and weak dc electric fields regulate nerve growth cone guidance in vitro. J Cell Sci 110:1957-65.
Fan J, Raper J (1995) Localized collapsing cues can steer growth cones without inducing their full collapse. Neuron 14:263-274.

Forscher P (1989) Calcium and polyphosphoinositide control of cytoskeletal dynamics. Trends Neurosci 12:468-74.

Gilman AG (1987) G proteins: transducers of receptor-generated signals. Annu Rev Biochem 56:615-649.

Goldberg D, Burmeister D (1986) Stages in axon formation: observations of growth of Aplysia axons using video-enhanced contrastdifferential interference contrast microscopy. J Cell Biol 103:1021-1031.

Goldberg DJ, Burmeister DW (1989) Looking into growth cones. Trends Neurosci 12:503-506.

Gomez TM, Letourneau P (1994) Filopodia initiate choices made by sensory neuron growth cones at laminin fibronectin borders in vitro. J Neurosci 14:5959-5972.

Goodman CS, Shatz CJ (1993) Developmental mechanisms that generate precise patterns of neuronal connectivity. Cell 72 [Suppl]:77-98.

Gunderson, RW (1987) Response of sensory neurites and growth cones to patterned substrata of laminin and fibronectin in vitro. Dev Biol 121:423-431.

Hamburger V, Hamilton HL (1951) A series of normal stages in the development of the chick embryo. J Morphol 88:49-92.

Hatta K, Takeichi M (1986) Expression of $N$-cadherin adhesion molecules associated with early morphogenetic events in chick development. Nature 320:447-449.

Keynes RJ, Stern CD (1984) Segmentation in the vertebrate nervous system. Nature 310:786-89.

Letourneau PC, Shattuck TA, Roche FK, Takeichi M, Lemmon V (1990) Nerve growth cone migration onto Schwann cells involves the calcium-dependent adhesion molecule, $N$-cadherin. Dev Biol 138:430-442.

Marsh L, Letourneau PC (1984) Growth of neurites without filopodial or lamellipodial activity in the presence of cytochalasin B. J Cell Biol 99:2041-2047.

McCobb DP, Cohan CS, Connor JA, Kater SB (1988) Interactive effects of serotonin and acetylcholine on neurite elongation. Neuron $1: 377-385$.

Ming G, Song H, Berninger B, Holt CE, Tessier-Lavigne M, Poo M (1997) cAMP-dependent growth cone guidance by netrin-1. Neuron 19:1225-1235.

Myers PZ, Bastiani MJ (1993) Growth cone dynamics during the migration of an identified commissural growth cone. J Neurosci 13:127-143.

Oakley RA, Tosney KW (1993) Contact-mediated mechanisms of motor axon segmentation. J Neurosci 13:3773-3792.

O'Connor TP, Duerr JS, Bentley D (1990) Pioneer growth cone steering decisions mediated by single filopodial contacts in situ. J Neurosci 10:3935-46.

Schuch U, Lohse MJ, Schachner M (1989) Neural cell adhesion molecules influence second messenger systems. Neuron 3:13-20.

Seilheimer B, Schachner M (1988) Studies of adhesion molecules mediating interactions between cells of peripheral nervous system indicate a major role for L1 in mediating sensory neuron growth on Schwann cells in culture. J Cell Biol 107:341-51.

Son Y-J, Thompson WJ (1995a) Schwann cell processes guide regeneration of peripheral axons. Neuron 14:125-132.

Son Y-J, Thompson WJ (1995b) Nerve sprouting in muscle is induced and guided by processes extended by Schwann cells. Neuron 14:131-411.

Song HJ, Ming GL, Poo MM (1997) cAMP-induced switching in turning direction of nerve growth cones. Nature 388:275-9.

Steketee M, Tosney KW (1999) Contact with isolated sclerotome cells steers sensory growth cones by altering distinct elements of extension. J Neurosci 19:3495-3506.

Stretavan DW, Reichardt LF (1993) Time-lapse video analysis of retinal ganglion cell axon pathfinding at the mammalian optic chiasm: growth cone guidance using intrinsic chiasm cues. Neuron 10:761-77.

Strittmatter S, Fishman MC (1991) The neuronal growth cone as a specialized transduction system. BioEssays 13:127-134.

Strittmatter SM, Valenzuela D, Kennedy TE, Neer EJ, Fishman MC (1990) $G_{o}$ is a major growth cone protein subject to regulation by GAP-43. Nature 344:836-481.

Tosney KW (1991) Cells and cell-interactions that guide motor axons in the developing chick embryo. BioEssays 13:1-7.

Wang Q, Zheng JQ (1998) cAMP-mediated regulation of neurotrophininduced collapse of nerve growth cones. J Neurosci 18:4973-4984. 